\title{
Demythologising factors associated with HIV and AIDS among Pentecostals: An effective way of dealing with the epidemic in South Africa
}

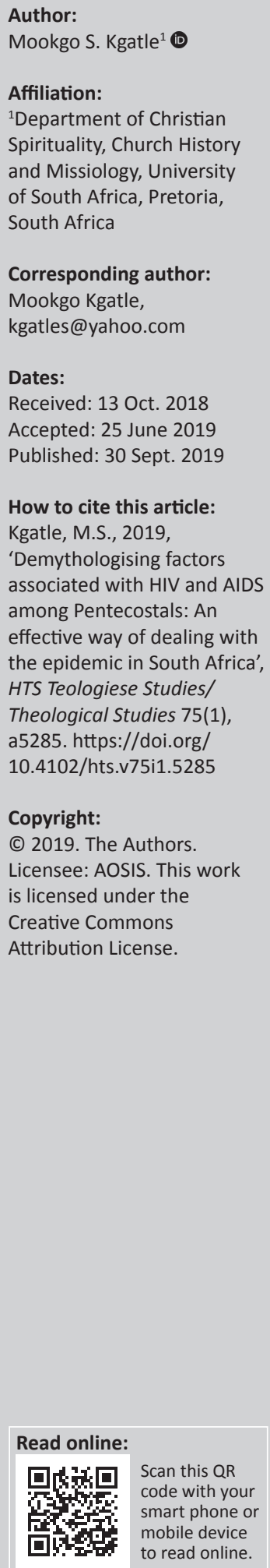

\begin{abstract}
The recent statistics on the prevalence of HIV and AIDS shows that the number of people living with the virus keep on increasing amidst government's interventions to deal with the epidemic. Pentecostal churches have a potential to deal with the problem, given their theology of experience, but are hindered by some myths about the factors associated with the epidemic highlighted in this article, such as the demonisation of sex and HIV and AIDS, judgemental views, denominationalism and condemnation of condoms. Many scholars interested in the study of HIV and AIDS have researched these myths. The unique contribution that this article makes is a proposal for a strategy of demythologisation of the factors associated with the epidemic among Pentecostals. The article uses a literary analysis to discuss effective ways of dealing with the epidemic in South Africa, such as to talk openly about sex, encourage safer sex, adopt a tolerant approach, embrace a holistic view and reconstruct a theology of HIV and AIDS.
\end{abstract}

Keywords: HIV and AIDS; Pentecostals; Theology; Sex; Condoms.

\section{Introduction}

The premise of this article is the persistent spread and increase in the number of people infected and affected by HIV and AIDS in South Africa. The numbers keep on growing despite the intervention of government to deal with the challenge. In the midst of these challenges, the government could be relying on the religious sector, especially Pentecostal churches, because of their growth and their hermeneutics of experience. In addition, Pentecostal churches can have a positive role in facilitating behaviour change with a large constituency on a weekly basis, affording opportunities for information sharing and teaching.

Like most other churches, Pentecostal churches uphold the principles surrounding family, marriage and sexuality; promoting abstinence outside of marriage; and fidelity within marriage. Therefore, they have the potential to be key role-players in combating the HIV pandemic (see Mash 2013:2). However, it is argued that the contribution of Pentecostal churches is hindered by their myths and some weaknesses on the factors associated with HIV and AIDS.

The importance of this article is not only to highlight these myths like demonisation of sex and HIV and AIDS, judgemental views, denominationalism and condemnation of condoms but also to demythologise them. Many publications highlight the myths and weaknesses of the religious sector in handling the issue of HIV and AIDS. One such important publication is a contributed work edited by Musa Dube (2003) HIV and AIDS and the Curriculum. Methods of Integrating HIV and AIDS in Theological Programmes. Various scholars like Agrippa G. Khathide, Johanna Stiebert, Madipoane Masenya, Tinyiko Sam Maluleke, Larry R. Colvin, André E. de la Porte and Prisca Mokgadi have addressed various topics ranging from curriculum to using the Bible to address HIV and AIDS. What is unique in this article is the study on the demythologisation of the factors associated with HIV and AIDS. The article demonstrates through a literary analysis that an effective way of dealing with the epidemic in South Africa is to talk openly about sex, encourage safer sex, adopt a tolerant approach, embrace a holistic view and reconstruct our theology of HIV and AIDS.

\section{Recent South African statistics on HIV and AIDS}

The recent statistics show that HIV and AIDS is an epidemic that continues to spread and steadily rise worldwide. Since the identification of the epidemic, more than 75 million people have contracted HIV and approximately 36 million have died from HIV-related causes. The Foundation 
for AIDS Research states that more than 35 million people now live with HIV and AIDS, and 3.3 million of them are under the age of 15. In 2012, an estimated 2.3 million new infections of HIV occurred and every day nearly 6300 people contracted HIV. In 2012, 1.6 million people died from AIDS (see Ballard 2014:4). The estimated overall HIV prevalence rate is approximately $13.1 \%$ among the South African population. The total number of people living with HIV was estimated to be approximately 7.52 million in 2018. Among adults aged $15-49$ years, an estimated $19.0 \%$ of the population is HIV-positive (Statistics South Africa 2018). These recent statistics demonstrates the rise of the epidemic, especially among the youth. It raises other questions like the education of young people on issues of sexuality as they relate to the spread of HIV and AIDS. One of the role-players to educate the young people is the church. The church cannot do this, if it is judgemental and shies away from issues related to HIV and AIDS. The church needs to open up to young people and ensure that they receive proper education on these issues.

\section{HIV and AIDS myths among Pentecostals \\ Demonisation of sex}

There is a connection between unprotected sex and HIV and AIDS. Although there are other ways in which infections of HIV and AIDS can occur, the fact remains that HIV and AIDS is a sexually transmitted disease. This alone makes unprotected sex to be at the centre of the spread and the rise of HIV and AIDS. The problem among some Pentecostals is the demonisation of sex for a long time. In the words of Atanassi (2009:vi), 'Pentecostals can be squeamish about sex, and yet it is impossible to talk about HIV without discussing sexual practices'. Adogame (2007) adds that:

First, HIV and AIDS discourses and perceptions evoke sentiments around religious and social ethics, morality/immorality, sexual promiscuity and infidelity: these are issues, which Pentecostals may not wish to identify with. (p. 476)

Pentecostals, especially in South Africa, are not at ease to talk about sex or even to write about it. In highlighting the reasons for this silence on issues of sex, Khathide (2003:4) opines that Pentecostals find it difficult to handle sex and sexualityrelated issues because they have considered sex as belonging to a domain outside the sovereignty of God. Although they may find it hard to admit, it is true that human beings, including the church, regard sex as something that is associated with darkness, evil and wickedness. Some people among Pentecostals seem to be comfortable with the fact that sex education is the responsibility of governments, schools and non-government organisations (NGOs). Thus, sex remains taboo to some Pentecostals. Even our African cultures have contributed to the present state of affairs in the sense that Africans in general are not free to talk about sex.

Other factors on the silence of Pentecostals on sex have to do with the fact that sexuality issues among Pentecostals are regarded as private matters, so those who speak about sexuality issues are regarded as naive and impolite (Mudau 2012:13). Be that as it may, but when people finally catch the virus, others will know that they are sexually active. Thus, the better option is to uncover the veil that hinders discussions on sex among the Pentecostals. Although the act of sex is a private matter, its likely consequences, as it could probably lead to HIV and AIDS, are very much public. Therefore, Pentecostals have to break the silence on sex issues by becoming more open on sex.

\section{Demonisation of HIV and AIDS}

The researcher has observed many Pentecostal pastors when praying for people infected with HIV and AIDS addressing HIV and AIDS a demon. This assertion by some Pentecostals makes them not to look at the factors that lead to the spread and the rise of HIV and AIDS because they see HIV and AIDS as a demon that needs exorcism. The fact that HIV and AIDS is still part of us means that it is not a demon but a sexually transmitted disease. Moreover, according to Adogame (2007:476), the social force of the demonisation of HIV and AIDS leads to fears that the involvement of Pentecostals in HIV and AIDS advocacy or care may be perceived as their endorsement or provision of cover to stigmatised groups such as gays or female sex workers. This social psychological dynamic may partly explain the continuing difficulty of mobilising Pentecostals in the fight against HIV and AIDS.

Given that the topics related to HIV often go unmentioned in churches (e.g. sexual intercourse, gender inequality, stigma and condoms), talking about HIV therefore is not an easy task (Atanassi 2009:34).

Furthermore, when HIV and AIDS is perceived as a demon, it means that it becomes a spiritual disease and not a biological and/or physical disease. Therefore, when Pentecostals are required to deal with its difficulty, they simply dismiss it as a demon and do not take responsibility for it. In most cases, the avoidance of medications leads to death and other consequences. Thus, Pentecostals need to un-demonise HIV and AIDS the same way they have to undemonise sex. If one cannot deal with a matter, it does not mean that it is a demon.

\section{Judgemental views}

HIV and AIDS is a sexually transmitted disease but that is not the only way one can be infected with the disease.

There are other ways where one can be in contact with the blood of an infected person, for example, an unborn child of an infected mother. Therefore, when a person is infected, it should not be concluded that the person has sinned against God and therefore God is punishing the person with HIV and AIDS.

According to Schau-Larsen (2011:16), contracting HIV has been viewed as the result of sinful behaviour, such as sex before marriage, unfaithfulness and encounters with prostitutes or 
homosexual conduct. These messages were heavily promoted among Pentecostals in the last three decades. Khathide (2003) adds:

Since the advent of HIV and AIDS the Pentecostals have showed some reluctance to get involved in the debate about the epidemic and the fight against it. Consequently, HIV and AIDS has been considered as God's punishment for the immoral corruption of humankind, a judgmental attitude which one hopes is no longer prevalent. (p. 1)

The background of the support to these messages is based on the fact that Pentecostals as a matter of principle forbid sex outside marriage. This means that young people need to abstain from sex until they get married and the married need to be faithful to their partners. Therefore, those who engaged in sexual activities outside marriage were considered to be breaking the rules and principles of purity. When a church member is infected with HIV, people in the church will begin to ostracise him or her for being a sinner. As a result, the epidemic is interpreted by some Pentecostals as a punishment from God for sexual transgressions or as a divine curse for immoral acts, namely, having premarital sex, being unfaithful to one's partner or behaving in ways that are contrary to certain religious teachings. They are too judgemental of people suffering from HIV and AIDS (see Mudau 2012:10). Thus, in the opinion of some Pentecostal pastors, lending a helping hand to the infected and the affected could be regarded as condoning the afflicted person's acts. Also, the Pentecostal pastors viewing the afflicted as 'sinners' or considering the epidemic as a 'curse' rather than adopting a compassionate and caring attitude greatly contributes towards to the stigma, discrimination, guilt and blame suffered by those affected by HIV and AIDS (Oluduro 2010:210).

\section{Denominationalism}

There is nothing wrong with belonging to/being loyal to a denomination. There is equally nothing wrong with the support of one's denomination by any means that one sees fit. The problem is the exaltation of one's denomination at the expense of other denominations. The other problem is to see one's denomination as being above other denominations. Thus, denominationalism is the assertion that one's denomination is not affected by the problem of HIV and AIDS but other denominations. Most church goers, according to Atanassi (2009:34), believe that they can prevent HIV infection through abstinence and faithfulness. They think that as these beliefs already coincide with their Christian values, AIDS should not be a problem in their church. Oluduro (2010:211) reiterates that there are some Pentecostals who think that the epidemic has not significantly affected their denominations or communities. Accordingly, they feel it was not their responsibility and adopted attitudes of passivity, inactivity, distance or mute indifference in the face of a monumental catastrophe. Consequently, they withdraw their support in the fight against HIV and AIDS because they are not affected by the challenge. There are some Pentecostals who think that HIV and AIDS is for sinners who misbehave and not for Christians who are holier than other people are.
Research conducted by Kolawole (2014:14) shows that churchgoing youth engage in risky sexual behaviour as do non-churchgoing youth. Most of the young people who test HIV-positive are deeply religious. Therefore, HIV and AIDS can affect those in the church as much as it can affect those outside the church. There must never be a way of isolating the challenges of HIV and AIDS from the church because it affects all of us in one way or the other. Therefore, there should be an adherence to the call made by House (2012:300) 'for the church to rise above her identity in ethnicity and gender, above denominationalism and sectarianism and get on with the business of making disciples of all nations'. Making disciples of all nations in this context does not necessarily mean to preach from the Bible but to take care of the people suffering with HIV and AIDS. Making disciples of all nations as it relates to HIV and AIDS means those suffering from the disease are equally children of God and God loves them.

\section{Condemnation of condoms}

The researcher remembers in his high school days when busy with Grade 12, the government in Limpopo had just started its campaign on educating young people on the so-called $A B C$ method, where A stands for Abstain, B for Be faithful and C for Condomise. One morning, a Limpopo government health representative had come to our school to teach about the use of condoms. The health representative had to illustrate the use of condom in front of all learners. The researcher was very much embarrassed that day and many of the School Christian Organisation (SCO) representatives shared the feeling. However, the reality is that many young people that morning needed that illustration and benefited from it because they were sexually active and the researcher was not. If someone is sexually active, they would rather use a condom than to engage in unprotected sexual intercourse. The message of abstinence and faithfulness will not assist them against HIV and AIDS but will leave them vulnerable to the virus.

Closer to the researcher's story, Stiebert (2001:175) shares another story of a young woman who was asked a question as to whether it was proper for a Christian to use condoms in order to protect himself or herself and/or a sexual partner from HIV and AIDS. The young woman, a first-year student, said to Stiebert that her pastor said 'it is wrong to use condoms'. The young woman's pastor might be right in the context of those who are born again and who are not supposed to have sex before they get married. This is because according to Siegel (2013:15), the born-again Pentecostals did not support condom use, because of their highest reported rates of abstention from pre- or extramarital sex. If true, this means that born-again Pentecostals should have lower HIV and AIDS rates. However, to those who cannot control themselves, it is better to use a condom.

However, the young woman's pastor is not alone in this condemnation of condoms. So many Pentecostal churches keep on saying 'you need to abstain' and 'you need to be faithful'; they condemn the use of condoms (see Woldehanna et al. 2005:42). 
It is good to minister faith-oriented concepts of sexual abstinence until marriage, and monogamous marriage with sexual fidelity relates closely to the first two components of the ABC approach to HIV prevention.

However, those whose faith is very weak need to hear an emphasis on condom use as they cannot abstain from sex or be faithful to their partners (see Mpofu et al. 2014:2). The problem is that some religious leaders of Pentecostal theological orientations were initially slow to respond to HIV and AIDS. As opposed to advocating condom use in their preaching, some Pentecostal churches, although small in number, took a moralistic view of HIV and AIDS as they preached messages that called for behavioural changes from 'immoral' lifestyles (House 2012:59). This moral stance by Pentecostal pastors is not wrong but does not cover other sectors of society. This can be dangerous because even unbelievers look up to church people for counsel and guidance.

Atanassi (2009:44) says that 'in discussions about condoms, pastors associated them with sinfulness, seeing them as signs of infidelity and promiscuity'. Schau-Larsen (2011:23) adds that 'most of them do not speak about condoms. Various Pentecostal pastors and HIV and AIDS councillors did not speak about condoms because condoms promote sex outside of marriage'. Some Pentecostal leaders described condoms as 'satanic' and 'promoters of sin'. The condemnation of condoms by Pentecostal pastors is risky because, according to Mash (2013:2), sexually active religious youths were less likely to use protection because of the linking of condoms with sin. Although religiosity may protect against initiating sexual activity, it may fail to protect against unsafe sex once youths are sexually active. Thus, the condemnation of condoms might work for those who are not sexually active but work against those who are sexually active.

The condemnation of condoms is not only a problem with Pentecostal pastors but also a general problem among many religious leaders across the world. Despite an avalanche of evidence in favour of sex education, some religious faiths, according to Oluduro (2010:214), still oppose it and are firmly against the use of condoms. They condemn the use of condoms, as it is seen as condoning illicit sexual relations. The use of condoms is depicted as an immoral, blunt and misguided weapon in the battle against HIV and AIDS. The Roman Catholic leaders who have been crucial players in virtually all aspects of the global response to HIV and AIDS since the disease was identified in 1981 have been at the forefront in the condemnation of the use of condoms. Adogame (2007:476) adds that in many countries, HIV and AIDS strategies, such as condom promotion, faced tremendous obstacles from religious organisations. Religious leaders often reach a deadlock with other stakeholders over condom use and mandatory testing before marriage. They may also have contributed to self-stigmatisation, which is common among followers who find themselves HIV-positive. Kolawole (2014:31) maintains that the Roman Catholic Church along with other minor religious sects opposes the use of condoms as they are regarded as immoral and a blunt and misguided weapon in the battle against HIV and AIDS. There is rather an emphasis on encouraging abstinence and being faithful to one's partner - an approach that has not necessarily proven to be effective in curbing the spread of HIV and AIDS.

\section{Demythologising factors associated with HIV and AIDS}

\section{Talking about sex}

The researcher is very passionate about teaching young people the issues of sexuality by presenting biblical principles that are related to sexuality and allowing the young people to ask questions thereafter. This method works especially in rural areas where young people still need more information on these issues. It does not really help to be silent on these issues. The fact is that even if pastors do not talk about these issues, somebody will talk about them. Oluduro hopes for a day when every church will engage in open dialogue on issues of sexuality and gender difference and where young people will learn about the facts of HIV and AIDS, when every synagogue will mobilise as advocates for a global response to fight against AIDS and when every temple will fully welcome people living with HIV. When that will happen, Oluduro is convinced that nothing will stop our success in the fight against AIDS (Oluduro 2010:208).

In order for Oluduro' s hopes to become a possibility, sex does not have to be seen as an evil act that should be punished, but as something created by God and also one that is natural. HIV and AIDS is a topic that is often rejected by churches and ignored because of the relationship it has with sexuality. Therefore, in order to deal with HIV and AIDS, there is a need to address issues of sexuality openly, that is, without fear and favour. This must be done in order to try to prevent further infections (Ballard 2014:28). In my view, this is the missing link which if corrected will enable the churches to win the war against HIV and AIDS. One of the challenges facing the church in addressing issues of sexuality is that adults do not want to be present when the young people receive such teachings. Mudau (2012:13) suggests that to make adults more comfortable, church leaders must separate them from the youth. Church leaders must create an environment that will make adults to speak freely about HIV and AIDS. When this is done, young people will also feel free to open up on these issues. As HIV and AIDS is largely a human sexuality issue, it is urgent to look into our attitude towards sex.

Unless this attitude changes, our fight against HIV and AIDS will become increasingly difficult (Khathide 2003:5).

\section{Encouraging safer sex}

The other issue that is very much close to issues of sexuality discussed above is the issue of condoms. It has been established above that many Pentecostal pastors shy away from talking about condoms because they feel like they will be supporting sexual immorality. This myth must be done away with in 
Pentecostal Christianity. Pentecostal pastors need to continue to preach the gospel of abstinence and faithfulness.

However, this gospel should be combined with the message of safer sex for those who are sexually active. It does not mean that the pastors will be compromising the truth but they will be facing reality and helping those with HIV-negative status to remain negative. Ballard (2014:28) suggests that instead of preaching a dialogue of pure abstinence, it is acknowledged that this is not always the case; therefore, safer sex needs to be practised. This is vastly different from what is thought to be a church's message; often, a message solely of abstinence before marriage is taught. However, in order to be competent, this cannot be the only message provided. They realise that pure abstinence by every member in the community is not a realistic goal, instead trying to promote safer sex using condoms and less sexual partners is much more practical.

People do not practise abstinence and faithfulness because they do not know about condoms. They do so because they are convicted of sin and are convinced to live a holy life in the name of the Lord. Equally so those involved in extramarital affairs and in pre-marital sex know that what they are doing is wrong. Therefore, encouraging safer sex is not to encourage immorality. After all, according to Schau-Larsen (2011:55), abstinence is the only $100 \%$ effective method against HIV. Condoms should only be used together with the message of abstinence and faithfulness. Mash (2013:4) adds that through participatory educational methods, young people can apply their spiritual values to the area of sexuality as well as develop a critical consciousness around their gender roles that protects them better from unsafe sex.

Therefore, organisations should not disparage condoms but advocate for their use by discordant couples, people having extramarital sex and couples in which one partner may be unfaithful. By educating families on the possibilities of Christian divorce and describing what Christian marriage entails, organisations can better address deep-seated beliefs about women's inferiority (Atanassi 2009:124). Recently, however, and in part as a result of public health education on $\mathrm{HIV}$, many churches are increasingly open to a broader set of health protection teachings. For instance, a substantial minority of Pentecostal churches endorse interventions that promote the use of condoms for preventing HIV transmission. There is a change in the ways in which Pentecostal youth understand risk for HIV and strategies for prevention in the context of faith-based organisations (Mpofu et al. 2014:2)

\section{Tolerant approach}

The Pentecostal church in general should not be judgemental of people who are infected with the HIV virus. They need to be flexible and not see people living with HIV and AIDS as people who are sinful but as the children of God because HIV and AIDS is a disease like any other disease. It should not be treated differently. The only difference with HIV and AIDS is that in some cases it is transmitted through sex. However, there are other medical reasons HIV infection and AIDS.
Therefore, according to Oluduro (2010:208), HIV and AIDS cannot simply be equated with an individual's lack of morality for several reasons. Many innocent children are born with HIV and AIDS, parents are infected through caring for their children without protective gloves and some people are victims of transfusion of contaminated blood. Furthermore, many faithful partners are infected by their unfaithful spouses, whilst innocent girls and women are infected through rape in and outside their homes. These reasons call for a more sensitive and tolerant approach when dealing with the issues of HIV and AIDS and people suffering from this disease.

There is a need to understand why some people who abstain from sexual relations, who are faithful and who use condoms still become infected. Thus, to generalise that people have HIV and AIDS because they do not live a faithful life and God is punishing them is wrong in many ways. It is too judgemental and it is too self-righteous. The issue of HIV and AIDS should be handled with care and sensitivity. While it might be true that some people live carelessly and contract the virus, not all people contract HIV and AIDS in a similar way. Moreover, even those who contract the virus through carelessness deserve a second chance in life. They need forgiveness and encouragement that when they take care of their lives they can live longer even if they are HIV-positive.

\section{A holistic view}

A tolerant approach needs to be complemented by a holistic view of HIV and AIDS. This should be done for the simple reason that a person encompasses a spirit that lives in a body and contains a soul. Thus, in dealing with HIV and AIDS, one cannot simply talk about the physical part but needs to address the person as a whole. When observing the healing ministry of Jesus, one realises that he dealt with a person as a whole. Sometimes, people are sick psychologically, others are not sick but need food or warmth in their lives, and then they become well. The same is the case with HIV and AIDS - it needs to be addressed holistically. Therefore, it cannot be denominational. It calls for the participation of all stakeholders. A holistic approach to HIV and AIDS ministry, according to House (2012:204), can address community members' needs in ways that, for example, public health officials often cannot perform. Public health can provide the scientific information concerning the epidemiology of disease; faith-based organisations, for example, can speak about the spiritual and psychological dimensions and the impact of the disease.

Atanassi (2009:5) says that 'Pentecostals have developed the ability to speak about church mission more holistically'. They need to apply this approach to the issue of HIV and AIDS. Pentecostals have the ability to look at the body, soul and the spirit of the person because they embrace a hermeneutic that is based on the work of the Holy Spirit. This, in my view, affords them an ability to look at the totality of an individual that is suffering from HIV and AIDS. Thus, Pentecostals need to abandon the politics of denominationalism and rather embrace people holistically. 


\section{Reconstruction of a theology of HIV and AIDS}

Reconstruction of a theology of HIV and AIDS means that theology needs to be relevant to contextual issues that many of our communities are facing on a day-to-day basis. When theology is reconstructed, it becomes relevant to issues like HIV and AIDS and will heed to the call for decolonisation and Africanisation of the curriculum in the sense that it will be addressing HIV and AIDS in our communities. There is a serious need, according to Mudau (2012:13), to adopt a new theology and speak about sexual issues - not only theology of the inner man but also theology of the spirit. The church has been engaged in the theology of spirit for too long.

To address the problem of HIV and AIDS in the church, it should form part of the theological doctrine of the church. In the presence of HIV and AIDS, there is a need to interpret the Bible in a new way.

There is a need to reconstruct our theology because, according to Masenya (2003:35), 'a theology which fails to address the most urgent questions asked by ordinary people is not theology at all'. Thus, Maluleke (2003:59) is surprised that 'given that HIV has created havoc in society that the subject has not dominated theological discourse'. In order to change this, the method of reading the Bible with and from the community can be used to generate and discover a contextually relevant theology of our time. Reading the Bible in the context of the community to highlight gender and other social injustices would serve well in our search for a healing theology at a time of HIV and AIDS (Dube 2003:10). The other method is to embrace what House calls 'Jesus theologies'. Jesus theologies, according to House (2012:175), were rooted in the lived religious experience of a theology of slaves. Such theology provided a hermeneutic key for interpreting their relationship with Jesus, who was their 'Almighty Friend' who affirmed their humanity. Thus, Jesus provided the oppressed with strength to face oppression in this life and offered the promise that he would be with them in the life to come.

From the discussions above, it may be concluded that the minister of religion in Africa has no choice but to face the reality of HIV and AIDS. There is a need for reconstructing the 'victim theology' of HIV and AIDS and to be ready to accept, without reservation, that HIV and AIDS is within the household of faith, domestic violence and reckless sexual behaviour are commonplace, and men (as much, if not more so than women) are the 'bearers' of HIV and AIDS (Oluduro 2010:227). Pentecostal commitments include following Scriptural principles and believing that God desires them to live abundant lives. Therefore, they need to address ways to help HIV-positive people live more abundant lives while maintaining faithfulness to Scripture (Atanassi 2009:111). Theologians cannot teach theology the way they have been doing up to now. Unless our own students are liberated from the fear and shame of talking openly about sex, they will not be able to deal with situations within their own lives and in the lives of the people; they are supposed to serve in the ministry (Khathide 2003:5).

\section{An effective way of dealing with the epidemic in South Africa}

The effective way of dealing with the epidemic in southern Africa is to talk openly about sex because the topic of sex and/or sexuality is very much related to the topic of HIV and AIDS given that HIV is sexually transmitted. Therefore, to deal with the problem of HIV and AIDS, Pentecostals need to freely engage with the topic of sex in a liberative way. Talking about sex will help the believers to open up when they face challenges in similar issues because the silence on sex causes believers to make mistakes and wrong life decisions. It is good to tell young people to abstain and to tell married couples to be faithful to each other, but the reality is that young people engage in sexual intercourse. Equally so, married couples engage in extramarital affairs. Without encouraging these practices, Pentecostals need to find a way to bring about a balance and encourage those who cannot abstain and be faithful to condomise. It is better to practise safe sex than to fall in the trap of HIV infection and unwanted pregnancies. Thus, it is important to reconstruct the theology of HIV and AIDS; theology cannot continue to isolate people who are suffering from the virus. People who are sick because of HIV and AIDS need to be ministered to in love and care. Theology must not condemn and judge people, especially those suffering from HIV and AIDS. According to Adogame (2007:477), there is a need for 'a spiritual commitment, religious involvement and socialization that take place within the context of the church to protect HIV and AIDS sufferers from the social stigma of the Disease'.

To enhance the lives of HIV-positive people, Pentecostal churches can also counter negative messages on HIV and AIDS by combining teachings about healing and living positively. Pentecostals need to be faithful to Scripture, and Scripture itself provides a counterbalance to abusive messages about people (see Atanassi 2009:111). Therefore, instead of judging and abusing people, Pentecostals need to have a tolerant approach towards people suffering from HIV and AIDS. A tolerant approach means that even if people fell in sin and caught the virus, they need forgiveness and a second chance in life - the same way everyone fell in sin and Christ gave them a second chance in life. A tolerant approach does not demonise HIV and AIDS but looks at it as a physical sickness that can affect anyone regardless of age, race, ethnicity, etc.

Hence, it is important to have a holistic view of HIV and AIDS than to view it in terms of a denominational issue or look at it as either a spiritual or a physical issue. HIV and AIDS affects the body, spirit and soul of an afflicted individual. Pentecostals with their theology of experience have an opportunity to minister to both the spirit and the physical nature of the person. Moreover, the mind of the person suffering from HIV and AIDS very much needs the power of the gospel.

There is also a need to move away from the mentality that church is only there to minister to its own people. The mission of the church is bigger than the people who are in the church. 
It is actually a mission to those outside the church. In this context, it means the mission of the church is actually to the infected people outside the church. If the mission of the church is seen in this way, the church will be able to preach the message of safe sex not because church people need that message but because the world needs that message. Pastors must not be indifferent to burying young people on a weekly basis but should be able to confront HIV and AIDS. The church must not be selfish but encompassing to reach more lost souls. This cannot be done if the church remains internal; it needs to reach out.

\section{Conclusion}

The recent statistics on HIV and AIDS show that the number of people living with the virus keeps on increasing amidst government's interventions to deal with the epidemic. The numbers show us that the group that suffers the most is young people. It is a sign that more work still needs to be done to educate these young people on issues related to HIV and AIDS. Hence, young people remain very gullible and vulnerable to the epidemic. This article observed that Pentecostal churches have the potential to deal with the problem given their growth and their theology of experience. However, it is found here that these churches are hindered by some myths on the factors associated with HIV and AIDS, such as the demonisation of sex and HIV and AIDS, judgemental views, denominationalism and condemnation of condoms. The conclusion in this article is that the demythologisation of the factors associated with HIV and AIDS among Pentecostals is an effective way of dealing with the epidemic in South Africa. Therefore, Pentecostals have to find a way to talk openly about sex, and encourage safer sex, a tolerant approach and a holistic view and reconstruction of the theology on HIV and AIDS. When this is done, the percentages of those living with the virus will surely decrease.

\section{Acknowledgements}

The author thanks the Department of Christian Spirituality, Church History and Missiology for support in conducting this study.

\section{Competing interests}

The author declares that no competing interest exists.

\section{Authors' contributions}

M.S.K. is the sole author of this article.

\section{Ethical consideration}

This article followed all ethical standards for carrying out research without direct contact with human or animal subjects.

\section{Funding}

This research received no specific grant from any funding agency in the public, commercial or not-for-profit sectors.

\section{Data availability statement}

Data sharing is not applicable to this article as no new data were created or analysed in this study.

\section{Disclaimer}

The views and opinions expressed in this article are those of the author and do not necessarily reflect the official policy or position of any affiliated agency of the author.

\section{References}

Adogame, A., 2007, 'HIV/AIDS support and African Pentecostalism: The case of the redeemed Christian Church of God (RCCG)', Journal of Health Psychology 12(3), 475-484. https://doi.org/10.1177/1359105307076234

Atanassi, K., 2009, 'Complex realities: Black South African women, HIV/AIDS, and Pentecostalism', Doctoral dissertation, Vanderbilt University.

Ballard, S., 2014, 'Responding to the HIV/AIDS epidemic in Africa: Churches United against HIV and AIDS', Undergraduate Honors Theses 38, viewed 04 April 2014 from https://scholar.colorado.edu/honr_theses/38.

Dube, M.W., 2003, 'Methods of integrating HIV/AIDS in biblical studies', in M.W. Dube (ed.), HIV/AIDS and the curriculum. Methods of integrating HIV/AIDS in theological programmes, pp. 10-23, World Council of Churches, Geneva.

House, C., 2012, 'Rhetoric (s) of the black church: Sex, religion, and HIV/AIDS across the African Diaspora', Doctoral dissertation, University of Pittsburgh.

Khathide, A.G., 2003, 'Teaching and talking about our sexuality: A means combating HIV/AIDS', in M.W. Dube (ed.), HIV/AIDS and the curriculum. Methods of integrating HIV/AIDS in theological programmes, pp. 1-9, World Council of Churches, Geneva.

Kolawole, O., 2014, 'Providing an effective legal framework for the protection of people living with HIV and AIDS in Nigeria', Doctoral dissertation, University of Cape Town

Maluleke, T.S., 2003, 'Towards an HIV/AIDS-sensitive curriculum', in M.W. Dube (ed.), HIV/AIDS and the curriculum. Methods of integrating HIV/AIDS in theological programmes, pp. 59-76, World Council of Churches, Geneva.

Masenya, M., 2003, 'Prophecy as a method of speaking about the HIV/AIDS epidemic in southern Africa', in M.W. Dube (ed.), HIV/AIDS and the curriculum. Methods of integrating HIV/AIDS in theological programmes, pp. 35-42, World Council of Churches, Geneva.

Mash, R., 2013, 'Faith based organisations and HIV prevention in Africa: A review', African Journal of Primary Health Care \& Family Medicine 5(1), Art. \#464, 1-6. https://doi.org/10.4102/phcfm.v5i1.464

Mpofu, E., Nkomazana, F., Muchado, J.A., Togarasei, L. \& Bingenheimer, J.B., 2014, 'Faith and HIV prevention: The conceptual framing of HIV prevention among Pentecostal Batswana teenagers', BMC Public Health 14(1), 225. https://doi. org/10.1186/1471-2458-14-225

Mudau, R.N., 2012, 'The attitudes of church members towards people living with HIV/ AIDS in the church', Doctoral dissertation, Stellenbosch University, Stellenbosch.

Oluduro, O., 2010, 'The role of religious leaders in curbing the spread of HIV/AIDS in Nigeria', Potchefstroom Electronic Law Journal/Potchefstroomse Elektroniese Regsblad 13(3), 208-236 https://doi.org/10.4314/pelj.v13i3.63673

Schau-Larsen, A., 2011, 'In God we trust: Christianity, Uganda and the AIDS epidemic', Doctoral dissertation, Concordia University.

Siegel, B., 2013, 'Neo-Pentecostalism in Black Africa', Anthropology Presentations, Paper 1, 1-26, Furman University Scholar Exchange: furman, viewed 17 March 2013 from http://scholarexchange.furman.edu/ant-presentations/1.

Statistics South Africa, 2018, Statistical release-statistics South Africa, viewed 23 July 2018, from www.statssa.gov.za.

Stiebert, J., 2001, 'Does the Hebrew Bible have anything to tell us about HIV/AIDS?', Missionalia: Southern African Journal of Mission Studies 29(2), 174-185.

Woldehanna, S., Ringheim, K., Murphy, C., Gibson, J., Odyniec, B., Clerisme, C. et al., 2005, Faith in action: Examining the role of faith-based organizations in addressing HIV/AIDS, Global Health Council, Washington, DC. 